\title{
Influence of Strategic Contract Management on Performance of Devolved Systems of Government in Kenya
}

\author{
Carren Chepng'etich $^{1 *} \quad$ Esther Waiganjo $^{2^{*}} \quad$ Noor Ismael $^{2}$ \\ 1.Procurement and Logistics Department, Jomo Kenyatta University of Agriculture and Technology \\ P.O Box 62000-00200 Nairobi, Kenya \\ 2.School of Entrepreneurship, Procurement And Management, Jomo Kenyatta University of Agriculture And \\ Technology, P.O Box 62000-00200 Nairobi, Kenya
}

\begin{abstract}
Many organizations have striven to cut down cost, in order to increase profits so as to gain competitive advantage this is realized through strategic procurement practices which helps an organization gain a competitive advantage through its contribution to the strategic goals of an organization and its ability to significantly increase performance and productivity. The purpose of this study was to investigate the influence of strategic contract management practice on performance of devolve system of government in Kenya, the study adopted cross-sectional survey design using both quantitative and qualitative approaches. The target population for this study were all employees working in finance and procurement departments in 10 counties namely; Garissa, Kisii, Nyamira, Narok, Marsabit, Murang'a, Bomet, Nairobi, Kiambu and Homa Bay the study used stratified random sampling to pick 186 respondents from finance and procurement department. Data was collected by using questionnaires Descriptive and inferential statistics was used aided by Statistical Packages for Social Sciences version 24 to compute percentages of respondents' answers. Hypothesis testing was carried using multiple regression analysis and standard $\mathrm{F}$ tests. The study found out that there is a moderate positive correlation association between strategic contract management and performance of devolved systems of government. The study recommends that all devolved systems of government should have explicit standards and measures of performance between different stakeholders and themselves and further the devolved systems of government should ensure obligations and responsibilities are well defined under contract before formalizing and signing the contracts.
\end{abstract}

Keywords: strategic contract management, supply chain performance, devolved systems of government.

DOI: $10.7176 / \mathrm{EJBM} / 12-21-12$

Publication date:July $31^{\text {st }} 2020$

\section{Introduction}

Devolve systems of government have been increasingly outsourcing public service provisions as a way of providing essential services to the public. Thus, public sector organizations are expected to achieve high performance standards in public provision (Boyne \& Walker, 2010) and this has enabled procurement to become strategic issue in the organizations. Procurement plays a strategic role in an organization's profitability and enhances shareholders value (Janda \& Seshadri, 2001). Strategic procurement deals with the purchasing of goods and services, including outsourcing of entire processes, so as to deliver better long-term shareholder value. It involves reducing the supplier base, co-operative negotiation with suppliers, quality interaction with suppliers, and developing long-term relationships with the best suppliers. Nevertheless, these strategic procurement behaviors are linked to better procurement performance (Ellram \& Zsidisin, 2003).

Globally, adoption and regulation of public expenditure has quickly gained momentum. Procurement is the acquisition of goods, services or works from an external source (Masurier, 2014). In state run institutions, governments across the globe continue to establish procurement systems to manage public expenditures. Capone (2016) opines the widespread regulation of public procurement to realized benefits in cutting costs and undertaking purchases competitively thus thereby improving the quality and value for the money. Since the beginning of the 90s, scholars have highlighted that procurement is becoming increasingly strategic in companies (Spekman et al., 1994). It is a well-recognized fact that companies have increasingly reorganized their business models to concentrate on core competences and outsourcing both operational and strategic activities and processes to external actors (Cousins et al., 2008). Companies have thus gradually become dependent on a multitude of relationships with suppliers. As a consequence of the strategic importance of supplier relationships, the procurement function becomes more and more crucial. This function performs more and more strategic activities; further, it develops and controls critical capabilities supporting and enhancing the company's competitive differential (Monczka et al., 2005).

In Kenya devolved system of government have been experiencing major challenges in the execution of procurement practices. The central government spends about Kshs. 234 billion per year on procurement. However, on annual bases, the government losses close to Ksh. 121 billion about 17 per cent of the national budget due to inflated procurement quotations (KISM, 2015). Also, according to the damning audit report for financial year 2014/15 a huge chunk of the monies were paid to unscrupulous workers or fictitious firms and non-existence 
suppliers in the county governments. Likewise, Odhiambo and Kamau (2013) established that although developing countries have taken steps to reform their public procurement systems, the process is still shrouded by secrecy, inefficiency, corruption and undercutting which has resulted to a huge amounts of resources into wastage. This is because majority of the devolved systems of governments do not adhere to strategic procurement practices and public procurement act and regulation, an example is the case of Bomet county where the county Government went against the public procurement and asset disposal act of 2015, which states that for a procuring entity to use direct procurement the following conditions must be met; a procuring entity may use direct procurement as allowed as long as the purpose is not to avoid competition; cases of disaster, war, catastrophic events and unforeseeable needs in these cases; needs of standardization and compatibility if these needs are reasonable and economic and finally for the acquiring of goods, works or services provided by a public entity provided that the acquisition price is fair and reasonable and compares well with known prices of goods, works or services in the circumstances(PPADA,2015). Bomet county rather used direct procurement when they were the hiring six ambulances from the Kenya Red Cross Society at a cost of Ksh600, 000 each per month (Business daily, 2017). Equally, an organization that practice strategic procurement would reduce supplier base and develop long term relationships with the best suppliers hence better performance (Boyne \& Walker, 2010; Ellram, 2003). It is therefore against this background this study is going to determine the influence of strategic contract management on the performance of devolved systems of government in Kenya.

\section{Objectives of the study}

The objective of this study was to determine the influence of strategic contract management on performance of devolved system in Kenya.

\subsection{Hypothesis of the Study}

$\mathbf{H}_{0}$ : Strategic contract management practice does not have a positive significance influence on performance of devolved systems of government in Kenya.

\section{Literature review}

\subsection{Contingency Theory}

This theory postulates that there is no one universally applicable set of management principles by which to manage organizations under all conditions. Organizations are individually different, face different situations (contingency variables), and require different ways of managing. Wren (2005) observes that contingency theory is a class of behavioural theory that claims that there is no best way to organize a corporation, to lead a company, or to make decisions. Instead, the optimal course of action is contingent upon the internal and external situation. Several contingency approaches were developed concurrently in the late 1960s. The authors of these theories argued that Marx Weber's bureaucracy and Fredrick Taylor's scientific management theories had failed as they neglected environmental influences and that there is not one best way to manage an enterprise (Ajzen, 2005). Thus, contingency variables include organization size, technology, environmental uncertainty, individual differences and many others. These variables influence and shape the individual behavior in a certain situation while managing firms.

Contingency theory is about the need to achieve fit between what the enterprise is and wants to become (its strategy, culture, goals, technology, staff and external environment) and what it does; how it is structured and the processes, procedures and practices it puts into effect (Purcell, Kinnie, Hutchinson, Rayton \& Swart, 2007). Thus, organizations are required to formulate different strategies in order to achieve their objectives. This is because a single strategy may not be appropriate due to the environmental influences. Rue and Byars (2004) argue that the contingency theory is an extension of humanistic theories where classical theories assumed universal view in managing enterprises; that is, whatever worked for one enterprise could work for another. The contingency theory states that there is no universal principle to be found in the management of enterprises but one learns about management by experiencing a large number of case problem situations and determines what will work for every situation (Wren, 2005). This is true because different counties have different unique challenge from one another. This theory is important to the counties of government in Kenya because it requires mangers to adopt different managerial skills in order to manage contracts with suppliers and other stakeholders. supply chain managers in the county government should implement predefined contingency plans to provide a quick response with appropriate mitigation measures to settle disputes among the parties. Thus contingency theory emphasizes the importance of procurement managers in the devolved government in Kenya to use strategies that are appropriate to the circumstances of the organization, including the culture, operational processes and external environment. Management strategies have to take account of the particular needs of the organization (Schuler \& Jackson, 1987 \& Dyer, 2005) 


\subsection{Conceptual Framework}

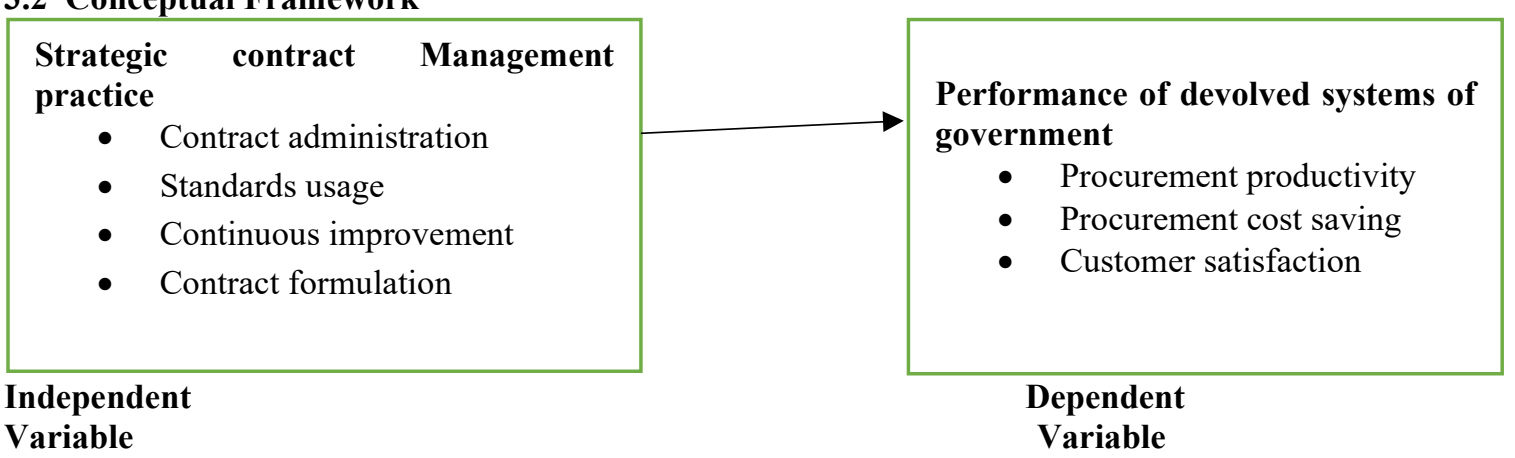

Figure 1: conceptual framework

\subsection{Contract management}

Contract management is the process of managing contracts entered in to with vendors, partners, customers, or employees. Contract management includes negotiating the terms and conditions of contracts and ensuring compliance with the terms and conditions, documenting and agreeing on any changes that may arise during its implementation or execution (Kumar \& Markeset, 2007). Hotterbeekx (2013) defined contract management as the process that ensures that all parties to a contract fully meet their obligations, in order to satisfy the operational objectives of the contract and the strategic business goals of the customer. Contract management can also be described as the process that allows both parties to the contract fulfill their obligations in order to meet the objectives required in the contract (Ferreira \& Marques, 2012).

According to Chartered Institute of Purchasing and Supplies (CIPS) (2012) key elements of contract management include: contract communication; contract administration; managing performance; relationship management; and contract renewal or termination. Effective contract management function can improve profitability, support compliance and manage risk in the organization (Woolcock, 2011). However, inefficient management of contracts can lead to poor operational control, low customer satisfaction, high risks and unwanted costs (Nguyen et al., 2013). For example, the study conducted by Woolcock (2011), revealed that there is a significant loss of money due to ineffective management of project contracts. Effective management and monitoring of contracts helps improve the quality of goods and services and reduces procurement cost thus achieving three broad goals of quality products and services, timely delivery of products and services, and cost effectiveness (Rotich, 2014). Chepngetich, Waiganjo and Karani (2016) assert that contract management leads to completion of projects within set budget and period.

Therefore, the aims of contract management in procurement are to ensure: services are delivered continuously and to a high standard, in accordance with the contract, and payments or penalties are made accordingly; contractual responsibilities and risk allocations are maintained in practice, and the parties responsibilities and risks managed efficiently; changes in the external environment such as both risks and opportunities are spotted and acted on effectively; the agreed allocation of risk is maintained and that best value is achieved; monitoring of the service provider's performance against the output specification is undertaken to ensure that the financial implications of any failure to perform have been taken into consideration and appropriate action taken; payment for the service is conditional upon the quality of performance of the service provider; services are delivered in accordance with the contract; continuous improvement in contract performance and service delivery is maintained (EPEC, 2014).

Likewise, contract management is to obtain the services under the contract and thereby maximize value for money (contract management guide, 2003). A study conducted by Chepng'etich, Waiganjo, and Karani, (2016), found out that effective contract management practice in Kenya Power and Lighting Corporation has led to completion of projects within set budget and period, has enabled the organization achieve competitive advantage and has led to reduction on supply chain costs. Thus, County governments should with weak contract management practice encourage corruption and lack of transparency which compromise the ideal of service quality and led to poor execution of contracts which in turn violates the principle of value for money (Burke, 2012).

\subsection{Performance of devolved systems of government}

The main objective of the organizations is to make profits, for this to be achieved it must be doing well on different functions of the organization, including procurement function. Procurement can play this important role by employing strategic procurement practices. Likewise, the main objective of devolution as provided is to promote social and economic development and the provision of proximate, easily accessible services throughout Kenya and to enhance government responsiveness to the needs of the citizens. The devolved system of government further aims at promoting equitable, efficient and prudent utilization of public resources (ministry of devolution and 
planning ,2016).

Sound public procurement policies and practices are essential elements of good governance (KIPPRA, 2006; World Bank, 2002). An ideal procurement system should always focus on effectiveness, where procuring entities should meet the commercial, regulatory and socio-economic goals of government in a manner that is appropriate to the procurement requirement. Wittig (1999) indicates that any improvements in the public procurement system can have a direct and beneficial effect on the overall economic situation of a country.

A Purchasing Magazine survey of consultants revealed a number of objectives that firms pursue when employing procurement strategy. They included driving the lowest possible purchase price, identifying sources of high-quality products/services, simplifying the purchasing and supply management processes, and reducing transaction costs. In addition, a leading consulting firm reported that companies use strategies to reduce transaction costs, purchase price, purchase order processing cycle times, and to speed up the time-to-market cycles (www.aberdeen.com 2003). Thus, this study will adopt lowest purchase price, high quality products/services, simplified procurement processes, procurement order processing cycle times and reduction transaction costs to measure performance of counties.

\section{Research methodology}

\subsection{Research design}

The study adopted cross-sectional survey design using both quantitative and qualitative approaches. The target population The target population for this study were all employees working in finance and procurement departments in 10 counties Garissa, Kisii, Nyamira, Narok, Marsabit, Murang'a, Bomet, Nairobi, Kiambu and Homa Bay. The study used stratified random sampling to pick 186 respondents from finance and procurement department. Data was collected by using questionnaires. Descriptive and inferential statistics was used aided by Statistical Packages for Social Sciences version 24 to compute percentages of respondents' answers. Hypothesis testing was carried using multiple regression analysis and standard $\mathrm{F}$ tests.

\subsection{Data collection instrument}

A standardized questionnaire was developed to capture the various variables under study. The questionnaire was divided into two sections. Part A was the organizational data. Part B asked the respondents to provide information concerning the major areas of this study. The questionnaire contained both closed and open ended questions. The closed ended questions were aimed at giving precise information which minimized information bias and facilitate data analysis, while the open ended questions gave respondents freedom to express themselves.

\subsection{Data Collection Procedure}

Questionnaire was self-administered to the respondents and two research assistants were recruited and trained which enabled the researcher get quality results. County employees were first contacted and the intention to drop the questionnaires and the request to explain to the procurement/finance managers. The questionnaires were delivered to the respondents and the researcher waited for them to be filled. At times the filling of the questionnaires was instantaneous, but most of the time the researcher will drop then come back for it after a while. The number of questionnaires that were used to collect data for this study were above 186 to increase high chances of respondents. Data collection was done between Jan- August 2019

\section{Research Findings and Discussion 5.1 Descriptive statistics}

The study sought to establish influence of strategic contract management on performance of devolved system of government. Five point Likert scale Statement questions were set for which the responses are presented in the table 2 . 
Table 2 Strategic Contract management practice

\begin{tabular}{|c|c|c|c|c|c|c|c|}
\hline Opinion Statements & $\begin{array}{l}\mathrm{SD} \\
(\%)\end{array}$ & $\begin{array}{c}\mathrm{D} \\
(\%)\end{array}$ & $\begin{array}{l}\mathrm{N} \\
(\%)\end{array}$ & $\begin{array}{c}\mathrm{A} \\
(\%)\end{array}$ & $\begin{array}{l}\text { SA } \\
(\%)\end{array}$ & Mean & $\begin{array}{c}\text { Std. } \\
\text { Deviation }\end{array}$ \\
\hline $\begin{array}{l}\text { Contract management helps in ensuring materials } \\
\text { and services delivered meet the required standards }\end{array}$ & 1.3 & 1.3 & 8.8 & 47.5 & 41.3 & 4.26 & 0.773 \\
\hline $\begin{array}{l}\text { There are explicit standards and measures of } \\
\text { performance between different stakeholders in } \\
\text { county government }\end{array}$ & 1.3 & 3.8 & 16.3 & 51.9 & 26.9 & 3.99 & 0.836 \\
\hline $\begin{array}{l}\text { Contract administration ensures obligations and } \\
\text { responsibility defined under contract are met }\end{array}$ & 1.3 & 0.6 & 16.3 & 50.0 & 31.9 & 4.11 & 0.782 \\
\hline $\begin{array}{l}\text { Contract management team emphasis on } \\
\text { continuous improvement and achievement of } \\
\text { results }\end{array}$ & 1.3 & 5.0 & 19.4 & 35.0 & 39.4 & 4.06 & 0.950 \\
\hline $\begin{array}{l}\text { Actors along the chain have efficient and secure } \\
\text { sources for collecting and analysing customer } \\
\text { information }\end{array}$ & 1.3 & 2.5 & 17.5 & 44.4 & 34.4 & 4.08 & 0.854 \\
\hline $\begin{array}{l}\text { Actors have good contract management skills to } \\
\text { win and retain customers and sell or purchase } \\
\text { items at favourable prices }\end{array}$ & 1.3 & 4.4 & 18.1 & 40.6 & 35.6 & 4.05 & 0.910 \\
\hline composite score & & & & & & 4.09 & 0.851 \\
\hline
\end{tabular}

From the study findings, it was revealed that majority of respondents strongly acknowledged that their devolved systems of government they participate in strategic contract management to help them in ensuring materials and services delivered meet the required standards and they have put explicit standards and measures of performance between different stakeholders in county government with a mean of 4.26. Secondly majority of respondents agreed that contract administration in their devolved systems of governments ensures obligations and responsibility defined under contract are met at a mean of 4.11. This findings concur with Rotich (2014) who noted that effective management and monitoring of contracts helps improve the quality of goods and services and reduces procurement cost thus achieving three broad goals of quality products and services, timely delivery of products and services, and cost effectiveness. further the actors along the chains have efficient and secure sources for collecting and analysing customer information as agreed by a mean of 4.08 .

\subsection{Correlation analysis}

To determine the strength and direction of the linear relationship between strategic contract management and performance of devolved systems of government, Pearson Product Moment Correlation was used and the results obtained are summarized in the below.

\section{TABLE 3: Correlation Matrix}

Strategic Contract management practice

\section{Correlations}

\begin{tabular}{l|l} 
performance of & Strategic Contract management
\end{tabular} Counties

\begin{tabular}{|c|c|c|c|}
\hline \multirow[t]{3}{*}{ performance of Counties } & $\begin{array}{l}\text { Pearson } \\
\text { Correlation }\end{array}$ & 1 & $.560^{* *}$ \\
\hline & Sig. (2-tailed) & & .000 \\
\hline & $\mathrm{N}$ & 160 & 160 \\
\hline \multirow[t]{3}{*}{$\begin{array}{l}\text { Strategic Contract management } \\
\text { practice }\end{array}$} & $\begin{array}{l}\text { Pearson } \\
\text { Correlation }\end{array}$ & $.560^{* *}$ & 1 \\
\hline & Sig. (2-tailed) & .000 & \\
\hline & $\mathrm{N}$ & 160 & 160 \\
\hline
\end{tabular}

\footnotetext{
**. Correlation is significant at the 0.01 level (2-tailed).
}

The correlation analysis results in table 2 above revealed that there was a moderate positive correlation association between strategic contract management and performance of devolved systems of government as supported by $(\mathrm{r}=0.560, \mathrm{p}=0.000)$. This results concurred with Chepng'etich, Waiganjo, and Karani, (2016) who found out that effective contract management practice in Kenya Power and Lighting Corporation has led to completion of projects within set budget and period, has enabled the organization achieve competitive advantage and has led to reduction on supply chain costs.

\subsection{Test of Hypothesis}

The researcher conducted regression analysis so as to establish the influence of strategic contract management on 
performance of devolved systems of government in Kenya. The hypothesis tested was:

$\mathrm{H}_{0}$ : Strategic contract management practice does not have a positive significance influence on performance of devolved systems of government in Kenya.

The $\mathrm{R}^{2}$ for the regression model between Strategic contract management practice and performance of devolved systems of government in Kenya was 0.314 meaning that Strategic contract management practice explain $31.4 \%$ variation in the performance devolve systems of government in Kenya while the remaining variation is explained by the error term.

\section{Table 4 Model Summary of strategic contract management practice}

\begin{tabular}{lrrrr|r} 
Model & $\mathrm{R}$ & \multicolumn{2}{c}{ R Square } & Adjusted R Square & Std. Error of the Estimate \\
\hline 1 & $.560^{\mathrm{a}}$ & .314 & .310 & .54669 \\
\hline
\end{tabular}

a. Predictors: (Constant), Strategic Contract management practice

Further test on ANOVA shows that the regression model was a good fit as indicated by a significant Fstatistic $(\mathrm{F}=72.297, \mathrm{p}<0.05)$. as indicated in the table below this implies that This implies that there is a moderate significant positive relationship between strategic contract management practice and performance of devolved systems of government. Therefore, strategic contract management improves performance of devolved systems of government in Kenya and supply chain and finance managers should ensure that they have set explicit standards and measures before awarding the contract to any suppliers. The findings are in agreement with the study of Rotich (2014) who noted that effective management and monitoring of contracts helps improve the quality of goods and services and reduces procurement cost thus achieving three broad goals of quality products and services, timely delivery of products and services, and cost effectiveness

Table 5 ANOVA a strategic contract management practice

\begin{tabular}{ll|r|r|r|r|r} 
Model & & Sum of Squares & df & Mean Square & F & \multicolumn{1}{c}{ Sig. } \\
\hline 1 & Regression & 21.607 & 1 & 21.607 & 72.297 & $.000^{\text {b }}$ \\
\cline { 2 - 8 } & Residual & 47.221 & 158 & .299 & & \\
\cline { 2 - 8 } & Total & 68.828 & 159 & & & \\
\hline
\end{tabular}

a. Dependent Variable: performance of Counties

b. Predictors: (Constant), Strategic Contract management practice

Further test on standardized regression coefficient for Strategic contract management practice was 0.560 . This indicates that a unit increase in the Strategic contract management practice would result in $56.0 \%$ increase in the performance devolve systems of government in Kenya. The t-statistic for the regression coefficient for Strategic contract management practice was significant at $5 \%$ level of significance $(\mathrm{T}=8.503, \mathrm{p}<0.05)$ implying rejection of null hypothesis. On the basis of these statistics, the study concludes that there is significant positive relationship between Strategic contract management practice and performance devolved systems of government in Kenya.

\section{Table 6 Coefficients ${ }^{\text {a }}$ of strategic contract management practice}

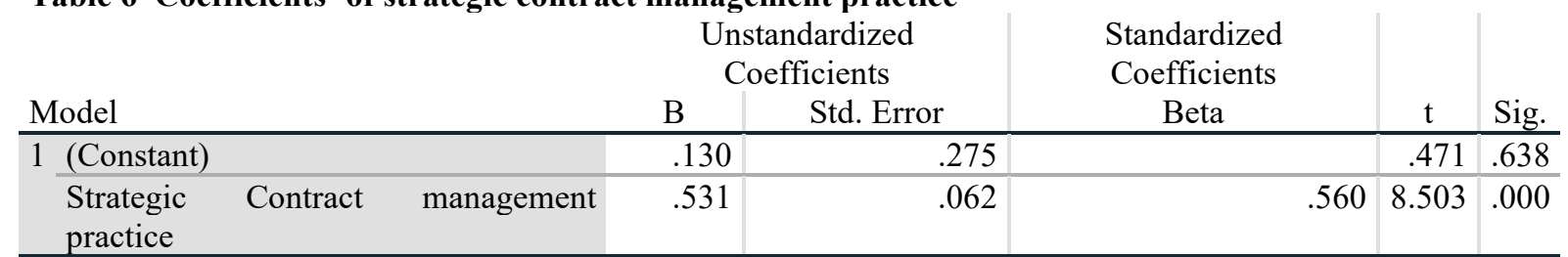

a. Dependent Variable: performance of Counties

\section{Conclusions}

From the findings, it could be concluded that strategic contract management practice has a positive influence on performance of devolved systems of government in Kenya. The study showed that there was moderate positive correlation association between strategic contract management and performance of devolved systems of government, hence it could be concluded that if supply chain and finance managers of devolved systems of government engage in strategic contract management, it could significantly enhance the performance of their organization. Although it was observed that management ensure proper management of the contracts, the study recommends that all devolved systems of government should have explicit standards and measures of performance between different stakeholders and themselves and ensure obligations and responsibilities are well defined under contract before formalizing and signing of the contracts and finally contract management teams should be put in place and continuously improved.

\section{REFERENCE}

Aberdeen Group. (2003). Aberdeen Group: The services supply chain automation benchmark report. Strategies for a buckshot market, Boston.

Ajzen, I. (2005). Attitudes, personality, and behavior. McGraw-Hill Education (UK). 
Business Daily (2017). Bomet tenders chief jailed for 5 years over ambulance fraud

Byars, L. L., \& Rue, L. W. (2004). Human reserved supply Management, ( $7^{\text {th }}$ ed.). McGraw-Hill Education (UK).

Chepng'etich,C., Waiganjo,E., \& Karani. A (2016). Influence of strategic sourcing on organizational performance of state corporation in Kenya; case of Kenya power. International Journal of Management and Commerce Innovation, 3, (2), 127-137

EPEC. (2014). Market Update: Review of the European PPP Market in 2013. Luxembourg: European PPP Expertise Centre.

D-a, C., Ferreira, N., \& Marques, R. C. (2012). Mixed companies and local governance: no man can serve two masters. Public administration, 90(3), 737-758.

Deutsche Bank, IUCN, LEAD, World Bank Institute, WBCSD 2002. Investing for Sustainable Development: Getting the Conditions Right. New York.IUCN, LEAD, World Bank Institute, WBCSD

Dyer, C. (2005). An age of transition?: economy and society in England in the later Middle Ages. Oxford University Press on Demand.

Giusti, T., Capone, P., \& Getuli, V. (2016). Design and Safety: From the EU Directives to the National Legislation. Building up business operations and their logic Shaping materials and technologies, 3(1), 652.

Hotterbeekx, J. M. H. (2013). Determining contract management professionalism within Rijkswaterstaat.Doctoral dissertation, Master thesis project, TUE. School of Industrial Engineering.

Janda, S., \& Seshadri, S. (2001). The influence of purchasing strategies on performance. Journal of Business \& Industrial Marketing, 16(4), 294-308.

Kumar, R., \& Markeset, T. (2007). Development of performance-based service strategies for the oil and gas industry: a case study. Journal of Business \& Industrial Marketing, 22(4), 272-280.

Kwok, T. Y., Nguyen, T. N., \& Lam, L. H. (2013). U.S. Patent No. 8,356,274. Washington, DC: U.S. Patent and Trademark Office.

Le--* Masurier, J. (2014). Briefing: affirming alliancing procurement for Christchurch rebuild, New Zealand. Proceedings of the Institution of Civil Engineers-Management, Procurement and Law, 168(1), 3-5.

Martin, M. G., \& Burke, R. J. (Eds.). (2012). Corporate reputation: Managing opportunities and threats. Gower Publishing, Ltd..

Ministry of Devolution and Planning (2016). Policy on Devolved System of Government

Mwangi, M. (2006). Highlights of the Public Procurement and Disposal Act, 2005 and the Draft Regulations 2006. Nairobi: KIPPRA.

Mohr, J., \& Spekman, R. (1994). Characteristics of partnership success: partnership attributes, communication behavior, and conflict resolution techniques. Strategic management journal, 15(2), 135-152.

Odhiambo, W., \& Kamau, P. (2013). Public Procurement: Lessons from Kenya, Tanzania and Uganda. OECD Working Paper NO.208. OECD Development Centre.

Partnerships Victoria. (2003). Contract management guide.

Petersen, K. J., Ragatz, G. L., \& Monczka, R. M. (2005). An examination of collaborative planning effectiveness and supply chain performance. Journal of Supply Chain Management, 41(2), 14-25.

Purcell, J., Kinnie, N., Swart, J., Rayton, B., \& Hutchinson, S. (2008). People management and performance. Routledge.

Rotich, C. J. (2014). Contract management practice and operational performance of state corporations in Kenya (Doctoral dissertation, Doctoral dissertation, Doctoral Dissertation, University of Nairobi).

Schuler, R. S., \& Jackson, S. E. (2005). A quarter-century review of human resource management in the US: The growth in importance of the international perspective. Management revue, 11-35.

Trudel, D., Horowitz, L., Wormuth, M., Scheringer, M., Cousins, I. T., \& Hungerbühler, K. (2008). Estimating consumer exposure to PFOS and PFOA. Risk Analysis, 28(2), 251- 269.

Walker, R. M., Boyne, G. A., \& Brewer, G. A. (Eds.). (2010). Public management and performance: Research directions. Cambridge University Press.

Wittig, W. (1999). Building value through public procurement: a focus on Africa. International Trade Centre.

Woolcock, A. (2011). Building A Culture Of Sustainability. ProSidian Consulting, LLC 09.14.

Wren, D. A. (2005). The history of management thought. John Wiley \& Sons.

Zsidisin, G. A., \& Ellram, L. M. (2003). An agency theory investigation of supply risk m anagement. Journal of supply chain management, 39(2), 15-27. 